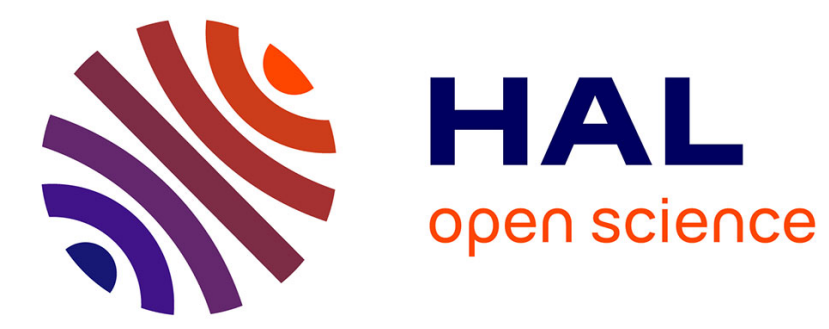

\title{
New optical sources for interstitial and metronomic photodynamic therapy
}

Serge Mordon

\section{To cite this version:}

Serge Mordon. New optical sources for interstitial and metronomic photodynamic therapy. Photodiagnosis and Photodynamic Therapy, 2018. hal-02736170

\section{HAL Id: hal-02736170 \\ https://hal.science/hal-02736170}

Submitted on 2 Jun 2020

HAL is a multi-disciplinary open access archive for the deposit and dissemination of scientific research documents, whether they are published or not. The documents may come from teaching and research institutions in France or abroad, or from public or private research centers.
L'archive ouverte pluridisciplinaire HAL, est destinée au dépôt et à la diffusion de documents scientifiques de niveau recherche, publiés ou non, émanant des établissements d'enseignement et de recherche français ou étrangers, des laboratoires publics ou privés. 


\title{
New optical sources for interstitial and metronomic photodynamic therapy
}

\author{
Serge Mordon, PhD. (orcid: 0000-0002-1208-7153) \\ INSERM, Univ. Lille, CHU Lille, U1189-ONCO-THAI-Image Assisted Laser Therapy for Oncology, Lille, F- \\ 59000, France.
}

\section{Highlights}

- In contrast to conventional optical fibers, which must be removed from the body soon after use, the biodegradable and biocompatible light sources may be used for longterm light delivery and need to be removed as they are gradually resorbed by the tissue. This letter aims to present two light sources which fulfill most of the requirements for iPDT and possibly for mPDT.

\section{Introduction}

Multiple clinical studies have shown that interstitial photodynamic therapy (iPDT) is a promising modality in the treatment of cancerous tumors in prostate, pancreas, head and neck cancer and brain. The laser fibers are into the target tissue inserted via needles, or placed in catheters ${ }^{1}$. However, the transport distance of light in biological tissues is limited by scattering and absorption. Practical therapeutic penetration depth is $0.1-1 \mathrm{~mm}$ for visible light in 400-600 nm and 2-3 mm for near infrared light in 700-1300 nm for most biological tissues. The fluence rate of therapeutic light must limited to prevent undesirable photothermal damage of tissues. The rate of oxygen consumption by the PDT process and the re-oxygenation rate of tissues may be also be an important consideration in deciding on fluence rate. Depending on photosensitiser and treatment site, lower fluence rates can also reduce pain problems. Consequently, when treating a large tumor, numerous lasers fibers must be inserted in the tumor. Moreover, except maybe for the brain, interstitial fibers cannot be left in tissue for a long period time. However, several studies have demonstrated 
that metronomic PDT (mPDT) based on continuous low rate delivery of photosensitizer and light, induces an enhanced induction of cell apoptosis as compared with a conventional PDT regimen ${ }^{2,3}$. Thus, mPDT could benefit for light sources placed inside the tumor tissue and emitting for several hours or days.

Recently, several teams have elaborated innovative implantable and biodegradable light sources that can be used for IPDT and mPDT in particular. In contrast to conventional optical fibers, which must be removed from the body soon after use, the biodegradable and biocompatible light sources may be used for long-term light delivery and need not be removed as they are gradually resorbed by the tissue. This letter aims to present two light sources which fulfill most of the requirements for iPDT and possibly for mPDT.

\section{Bioabsorbable polymer optical waveguide}

The first innovative light emitting light source was developed by Nizamoglu et al. ${ }^{4}$.It is made of transparent and flexible poly(L-lactic acid) biopolymer. Polymers offer a wide range of biodegradation half-times, from 1 min to over a year ${ }^{5}$. The relative amount of GA (Glycolide acid) in PLA (poly(L-lactic acid)) increases the biodegradation rate in PLGA (poly (D,L-lactideco-glycolide). Besides, lactide and glycolide-based copolymers are degraded by ester hydrolysis and break into monomers, which are further degraded and resorbed in the body with minimal systemic toxicity. Therefore, these polymers are chosen for making a resorbable light source. The solid waveguide is achieved by melt-pressing technique. Its dimensions are obtained by precise laser cutting. Consequently, this waveguide can be easily shaped. Nizamoglu et al designed a waveguide similar to a trident to perform photochemical tissue bonding. In this application, a standard multimode optical fiber ( $200 \mu \mathrm{m}$ core, $0.48 \mathrm{NA})$ is bonded to the waveguide using an optical adhesive. This optical fiber is connected to a 532$\mathrm{nm}$ laser. Tests performed at $1 \mathrm{~W}$ and 15 minutes duration demonstrated the efficiency of this new device (see figure 1). Long term evaluation of this waveguide was not performed and biodegradability and toxicity were not evaluated. However, this new device is very promising due to relative ease of manufacture and ability to deliver substantial light intensities. 

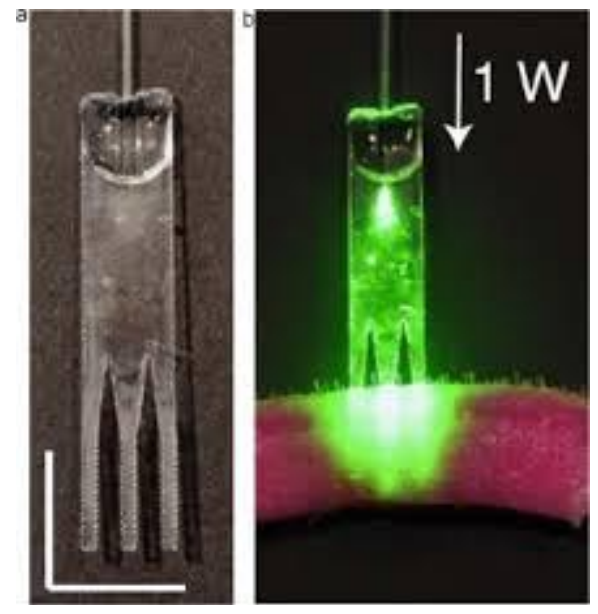

Figure 1: Hybrid biopolymer-based waveguide bundle engineered for optimal light delivery to the tissue. Scale bars, $10 \mathrm{~mm}$ (from ref 4 )

\section{Near-infrared rechargeable "optical battery"}

Another very innovative approach has been recently proposed by Hu et al ${ }^{6}$. This team has developed a near infrared (NIR) rechargeable "optical battery" implant for irradiation-free continuous PDT. By combining the NaYF4:25\%Yb,0.5\%Tm upconversion materials with typical UV/blue upconversion emission (350/475 nm) and UV rechargeable SrAl2O4:2\%Eu2p,4\%Dy3p persistent phosphors (mass ratio, 1: 10), a green persistent luminescence at $520 \mathrm{~nm}$ can be activated by $980-\mathrm{nm}$ NIR excitation due to the spectra overlapping between the upconversion emissions and absorption of persistent phosphors. The mixture was added into PDMS (biocompatible polydimethylsiloxane) and placed to special molds and degassed under vacuum for $30 \mathrm{~min}$. The PDT optical battery can be obtained after solidify at $60^{\circ} \mathrm{C}$ for $1 \mathrm{~h}$ and can be easily fabricated into any size and shape. Figure 2 shows several examples such as microneedles, wire, hollow tube or membrane (figure 2)
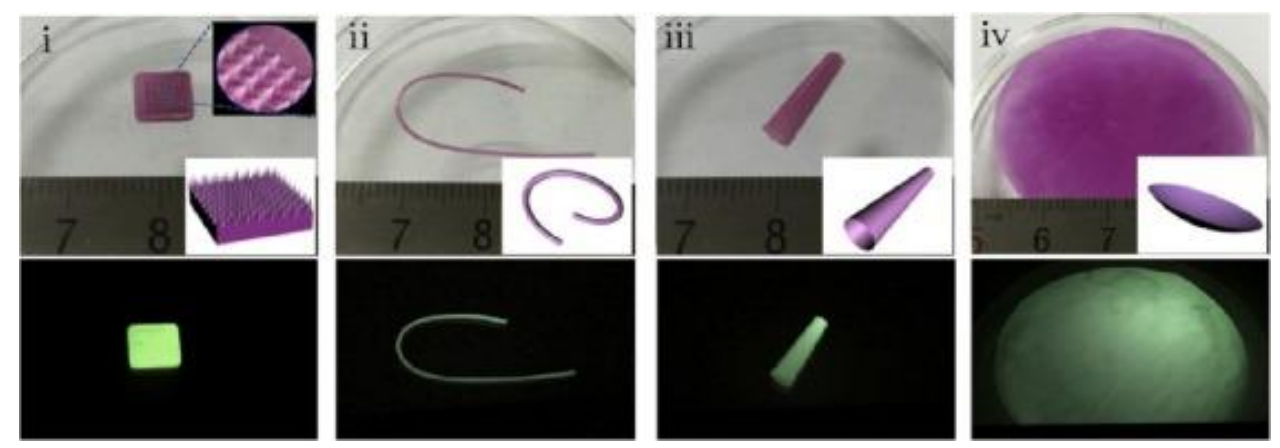

Figure 2: Photographs and 3D diagrams of the PDT implants with different shapes. i) PDT microneedles; ii) PDT wire iii) PDT hollow tube; iv) PDT membrane (from ref 6). 
After short (5 s) charging process by $980-\mathrm{nm}$ laser, the "optical battery" implant can generate green persistent luminescence for 30 minutes. $2 \mathrm{~W} / \mathrm{cm}^{2}$ is enough to full charge the persistent materials without any overheating of the surrounding tissues. Furthermore, the PDT "optical battery" implant can still be charged to continuously generate singlet oxygen even in deep tissue as high as $4 \mathrm{~mm}$ because of the deep tissue penetration of the NIR charging source. Due to the facile preparation, flexible and bio-stability of PDMS (biocompatible polydimethylsiloxane), the irradiation-free PDT implant can be easily optimized in size and shape aiming at different nidus sites

By adding the photosensitizer inside the battery, ${ }^{1} \mathrm{O}_{2}$ can be continuously generated under persistent luminescence. Hu et al evaluated Rose Bengal which is known to be a potent photosensitizer ${ }^{7}$. An experiment was performed on HT29 tumor implanted subcutaneously into mice (figure 3). Results clearly demonstrate that this implantable O2-generating PDT device greatly decreased the tumor volume of the mice after two NIR irradiation per day for 15 days.

Upconversion materials such NaYF4 have potential toxicity problems. However compared to upconversion nanoparticles, there is no IV injection ${ }^{8}$. At last, the degradation of this optical battery should be studied carefully.

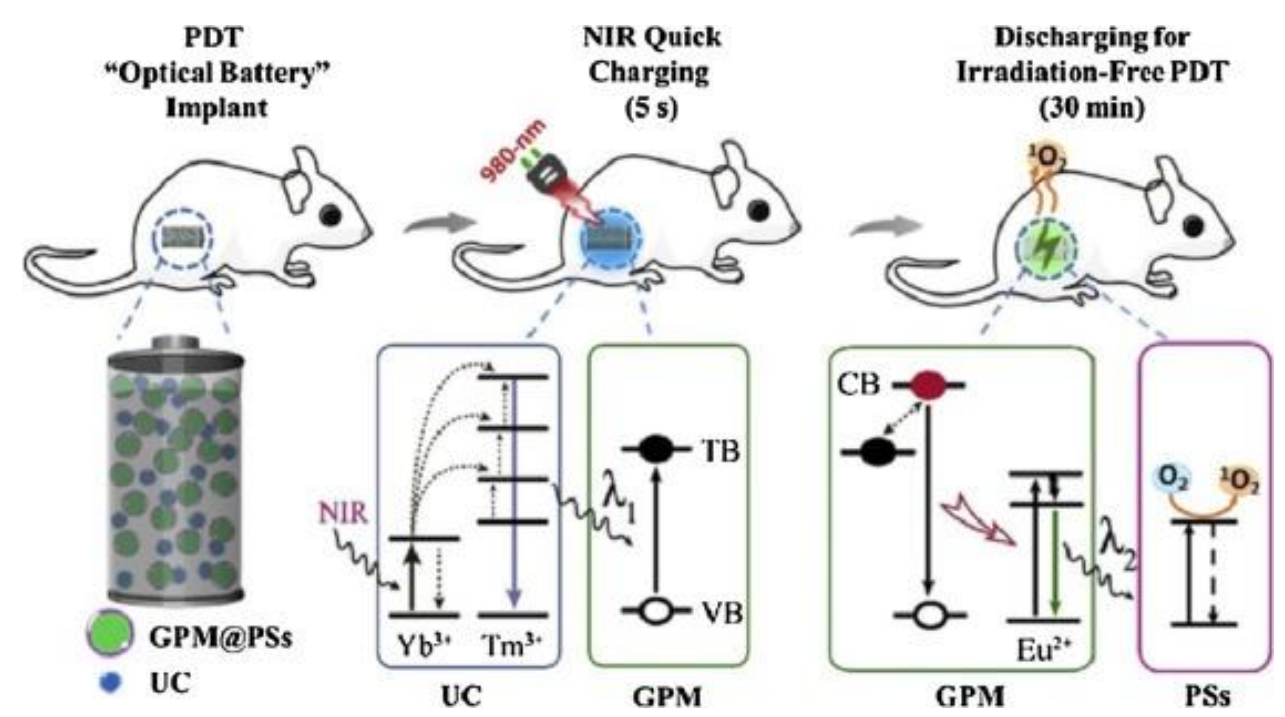

Figure 3: Schematic illustration of the NIR light rechargeable persistent luminescence activated PDT "optical battery" implant for tumor inhibition (GPM: green persistent luminescence materials; PSs: photosensitizers; UC: upconversion materials; TB: trapping band; VB: valence band). (from ref 6) 


\section{Conclusion}

These innovative bioabsorbable waveguides and optical batteries may initiate a new paradigm and find widespread use in medicine. The use of polymers such as polydimethylsiloxane, PLA or PLGA,.. give a great adaptability of size and shape to specifically target a nidus site. Further studies should evaluate the safety of the biodegradation process which will be required in order to approve these light sources on humans.

\section{References}

1-Shafirstein G, Bellnier D, Oakley E, Hamilton S, Potasek M, Beeson K, Parilov E. Interstitial Photodynamic Therapy-A Focused Review. Cancers (Basel). 2017 Jan 24;9(2).

2- Davies N, Wilson BC. Tetherless fiber-coupled optical sources for extended metronomic photodynamic therapy. Photodiagnosis Photodyn Ther. 2007 Sep;4(3):184-9.

3- Guo HW, Lin LT, Chen PH, Ho MH, Huang WT, Lee YJ, Chiou SH, Hsieh YS, Dong CY, Wang HW. Low-fluence rate, long duration photodynamic therapy in glioma mouse model using organic light emitting diode (OLED). Photodiagnosis Photodyn Ther. 2015 Sep;12(3):504-10.

4- Nizamoglu S, Gather MC, Humar M, Choi M, Kim S, Kim KS, Hahn SK, Scarcelli G, Randolph M, Redmond RW, Yun SH. Bioabsorbable polymer optical waveguides for deep-tissue photomedicine. Nat Commun. 2016 Jan 19;7:10374.

5- Ratner, B. D., Hoffman, A. S., Schoen, F. \& Lemons, J. E. Biomaterials Science: an Introduction to Materials in Medicine 162-164, 2004).

6-Hu L, Wang P, Zhao M, Liu L, Zhou L, Li B, Albaqami FH, El-Toni AM, Li X, Xie Y, Sun X, Zhang F. Near-infrared rechargeable "optical battery" implant for irradiation-free photodynamic therapy. Biomaterials. 2018 May;163:154-162.

7-Song L, Li C, Zou Y, Dai F, Luo X, Wang B, Ni J, Liu Q. O2 and Ca(2+) fluxes as indicators of apoptosis induced by rose bengal-mediated photodynamic therapy in human oral squamous carcinoma cells. Photomed Laser Surg. 2015 May;33(5):258-65.

8- Hamblin MR. Upconversion in photodynamic therapy: plumbing the depths. Dalton Trans. 2018 Feb 16. doi: 10.1039/c8dt00087e. 